\title{
Correlations Between the Collagen Content of the Human Left Ventricular Myocardium, Measured by Biochemical and Morphometric Methods
}

\author{
José Duarte de Morais Lopes, Roseli Aparecida da Silva Gomes, Valdemar Hial, \\ Isabel Cristina Rezende Lopes, Marlene Antônia dos Reis, Vicente de Paula Antunes Teixeira \\ Uberaba, MG - Brazil
}

\begin{abstract}
Objective - To assess, in myocardium specimens obtained from necropsies, the correlation between the concentration of hydroxyproline, measured with the photocolorimetric method, and the intensity of fibrosis, determined with the morphometric method.
\end{abstract}

Methods - Left ventricle myocardium samples were obtained from 45 patients who had undergone necropsy, some of them with a variety of cardiopathies and others without any heart disease. The concentrations of hydroxyproline were determined with the photocolorimetric method. In the histologic sections from each heart, the myocardial fibrosis was quantified by using a light microscope with an integrating ocular lens.

Results - A median of, respectively, 4.5 and $4.3 \mu \mathrm{g}$ of hydroxyproline/mg of dry weight was found in fixed and nonfixed left ventricle myocardium fragments. A positive correlation occurred between the hydroxyproline concentrations and the intensity of fibrosis, both in the fixed $(\mathrm{Sr}=+0.25 ; p=0.099)$ and in the nonfixed $(\mathrm{Sr}=+0.32$; $p=0.03)$ specimens.

Conclusion - The biochemical methodology was proven to be adequate, and manual morphometry was shown to have limitations that may interfere with the statistical significance of correlations for the estimate of fibrosis intensity in the human myocardium.

Key words: heart, hydroxyproline, morphometry

Faculdade de Medicina do Triângulo Mineiro - Uberaba, Brazil Mail to: Vicente de Paula Antunes Teixeira - Curso de Pós-graduação em Patologia da Faculdade de Medicina do Triângulo Mineiro - Rua Frei Paulino, 30 - 38025-180 Uberaba, MG, Brazil - E-mail: vicpat@mednet.com.br
The main protein constituent of the extracellular myocardial matrix is collagen ${ }^{1}$. Electrophoresis analyses helped to establish that collagen types I and III are predominant in the myocardium ${ }^{1,2}$, which was also found by histologic techniques ${ }^{3}$. However, at least 3 other collagen isoforms are believed to be present in the myocardium: types IV, V, and $\mathrm{VI}^{4-8}$. Type I is the most abundant of all these types, corresponding to approximately $80 \%$ of the total myocardial collagen, followed, in quantitative terms, by type III, which corresponds to approximately $12 \%{ }^{9}$.

Almost all the hydroxyproline present in the human body stems from the hydroxylation of proline residues, during the posttranslation processing of the procollagen $\alpha$ chains ${ }^{10}$. Although it is also found in other proteins, such as elastin, the C1q component of the complement system and acetylcholinesterase ${ }^{11}$, hydroxyproline is considered characteristically a collagen amino acid, and its determination by various methods can be considered as an indicator of the tissue collagen content ${ }^{11,12}$.

The collagen content of the myocardium can be estimated by considering that $100 \mathrm{~g}$ of collagen contain approximately $13.4 \mathrm{~g}$ of hydroxyproline ${ }^{13,14}$. It must however be taken into account that elastin is also one of the constituents of the extracellular myocardial matrix. Yet, the contribution of the hydroxyproline contained by elastin is considered negligible with regard to the total content of this amino acid or, more appropriately, imino acid in the myocardium, not only because its amount in elastin is very small as compared with the amount present in collagen, but also because the myocardium of humans and of test animals that are not affected by any kind of disease contains much more collagen than elastin ${ }^{15}$.

Although studies exist about the quantification of collagen in the heart by biochemical, morphometric methods, or both, reports about investigations comparing results obtained by both methods are rare. The hypothesis raised by 
the authors is that the intensity of fibrosis in the myocardium can be evaluated both by histomorphometry and by the biochemical dosage of hydroxyproline. In this study, an attempt was made to quantify collagen by the biochemical and the morphometric methods in fragments of the left ventricular myocardium fixed in $10 \%$ formalin and in nonfixed fragments, and to verify whether a correlation exists between the 2 methods.

\section{Methods}

Fragments of the left ventricular myocardium of 45 patients who had undergone necropsy within 36 hours after death were collected at the Hospital Escola da Faculdade de Medicina do Triângulo Mineiro (Uberaba, MG, Brazil); $33(73.3 \%)$ of them were males. The patients' ages ranged from 16 to 80 years, the mean being $51 \pm 17.2$ years.

No cardiopathy was present in $23(51.1 \%)$ patients. Of the 22 cases with a cardiopathy, 7 had chronic Chagas disease, 12 had hypertension, 6 had ischemia, 5 had chronic cor pulmonale, and 1 had chronic rheumatic heart disease. An association of cardiopathies existed in 9 cases. From each heart, a $2.0 \times 2.0 \times 0.3-\mathrm{cm}$ fragment of the left ventricular myocardium was removed at the upper third of the free left ventricle wall. After removing the epicardium and the endocardium, each fragment was cut into 6 fragments of $0.3 \times 0.3$ $\mathrm{x} 0.3-\mathrm{cm}$ each. Three of these fragments were placed in a glass tube containing $15 \mathrm{~mL}$ of $10 \%$ formalin, and the other 3 in another tube containing $15 \mathrm{~mL}$ of ethyl ether P.A. (for analysis); both tubes were kept in a freezer until the biochemical determination of the hydroxyproline concentration.

Fragments of the left ventricular myocardium were also collected, fixed in $10 \%$ formalin, routinely processed and embedded in paraffin for histopathologic and morphometric analyses. The blocks made in this manner were cut with a microtome to obtain $6-\mu \mathrm{m}$ thick sections, which were placed onto glass slides and stained by the hematoxylin-eosin and picrosirius techniques.

For the biochemical determination of the hydroxyproline concentration, Bergman and Loxley's method ${ }^{16}$ modified by Medugorac ${ }^{17}$ was used. This technique can be considered an improvement of Neuman and Logan's method ${ }^{12}$. According to these authors, the collagen content of a given tissue sample can be estimated from its hydroxyproline concentration, by multiplying its value by 7.46 , since this imino acid represents $13.4 \%$ of collagen. Each fragment was dehydrated in $1 \mathrm{~mL}$ acetone P.A. for 1 hour at room temperature, and degreased in $2 \mathrm{~mL}$ petroleum ether P.A. for 2 hours. Following petroleum ether removal, the fragments were dried, initially in an incubator at $110^{\circ} \mathrm{C}$ for 30 minutes, and then in a lyophilizer at $-40^{\circ} \mathrm{C}$ and a negative pressure of 20 millibars for 24 hours. After drying, the fragments were weighed with a digital analytical balance to obtain their dry weights. Then each fragment was placed in a 5-mL glass flask containing $100 \mu \mathrm{L}$ of $\mathrm{HCl} 6 \mathrm{~N}$. The flasks were hermetically closed by using a Bunsen burner and placed in an incubator at $110^{\circ} \mathrm{C}$ for 12 hours. The flasks were then opened and the hydrolysate was resuspended in $1 \mathrm{~mL}$ of $\mathrm{HCl} 1 \mathrm{mM}$, transferred to 1.5-mL Eppendorf tubes for centrifugation at 3,000 rpm for 5 minutes room temperature. The supernatant was used for the photocolorimetric determination of hydroxyproline concentration.

The determinations of hydroxyproline concentration in the left ventricular myocardium, hydrolysates were made in triplicates. To each test tube the following reagents were added, in this order: (1) $100 \mu \mathrm{L}$ of hydrolysate; (2) $400 \mu \mathrm{L}$ of $\mathrm{HCl} 1 \mathrm{mM}$; (3) $1 \mathrm{~mL}$ of isopropanol P.A.; and (4) $500 \mu \mathrm{L}$ of an oxidant solution prepared by diluting 1 volume of a $7 \%$ trihydrated chloramine-T solution P.A. in bidistilled water with 4 volumes of citrate buffer, pH 6.0, making up a total volume of $2 \mathrm{~mL}$. Standard solutions of 1.0, 2.0,4.0, 8.0, and $16.0 \mu \mathrm{g} / \mathrm{mL}$ of hydroxyproline were also prepared in triplicate to make a calibration curve. To the tubes corresponding to the standard solutions, the same volumes of $100 \mu \mathrm{L}$ of hydroxyproline standard solution, $1 \mathrm{mM} \mathrm{HCl}$, isopropanol, and oxidant solution were added as to the tubes containing the hydrolysates. A blank was also prepared in triplicate, by adding $500 \mu \mathrm{L} 1 \mathrm{mM} \mathrm{HCl}$ instead of hydrolysate or standard solution. All tubes were left to rest at room temperature for 4 minutes. After that, to each tube $1 \mathrm{~mL}$ of Ehrlich's reagent was added, freshly prepared by mixing $17.6 \mathrm{~g}$ paradimethylaminobenzaldehyde P.A. with $23.3 \mathrm{~mL}$ perchloric acid P.A. and completing the volume to $1 \mathrm{~L}$ with isopropanol P.A. Immediately afterwards, all tubes were incubated in a water bath at $60^{\circ} \mathrm{C}$ for 21 minutes, then transferred to an ice bath and left to rest for 60 minutes. The optical densities at 562 $\mathrm{nm}$ were measured by using a spectrophotometer.

To evaluate the yield of this method, triplicate standard solutions were prepared at the concentrations specified earlier. One $\mu \mathrm{g}$ hydroxyproline was added to these solutions. All tubes used for this purpose were submitted to the same treatments as the tubes containing the hydrolysates and also to the hot acid hydrolysis procedure.

The hydroxyproline concentration values obtained by using the calibration curve were corrected taking into account the yield of this method. After these corrections, the concentrations were converted to $\mu \mathrm{g}$ hydroxyproline/mg of dry tissue weight.

The morphometric quantification of myocardial fibrosis was made by using an integrating ocular lens (Carl Zeiss, Germany) containing a reticulum with 25 randomly distributed dots. The ocular was connected with an ordinary light microscope with a $10 \mathrm{X}$ objective, providing a final enlargement of $100 \mathrm{X}$. The reticulum was projected on each microscopic field of the myocardium, and the dots that were coincident with fibrous tissue were counted. For each histologic section, counts were made on 60 fields, and 1,500 were examined per section. For each case, the percentage of dots coincident with fibrosis was calculated. Fibrosis quantification was carried out on sections stained by picrosirius, examined under standard or polarized light, after previous analysis of the slides stained with HE. 
The distributions were tested with the KolmogorovSmirnov normality test. Because they all were shown not to be normal, the Wilcoxon test and Spearman's rank coefficient were used. The observed differences were considered significant whenever $\mathrm{p}<0.05$.

\section{Results}

The medians of the hydroxyproline concentrations in the formalin-fixed or nonfixed left ventricular myocardium specimens were $4.50 \mu \mathrm{g}$ hydroxyproline/mg dry tissue weight and $4.30 \mathrm{mg}$ hydroxyproline/mg dry tissue weight, respectively. The median of the fibrosis percentage was $11.41 \%$ (Table I).

The correlation between the hydroxyproline concentrations in the fixed left ventricular myocardium specimens and the fibrosis percentage was positive and nonsignificant $(\mathrm{Sr}=0.25 ; \mathrm{p}=0.099)$. On the other hand, the correlation between the hydroxyproline concentrations in the nonfixed specimens and the fibrosis percentage was also positive, yet statistically significant $(\mathrm{Sr}=0.32 ; \mathrm{p}=0.03)$ (Figure 1$)$.

\section{Discussion}

Regardless of the left ventricular myocardium specimens being fixed or nonfixed, the results shown regarding hydroxyproline concentration do not differ from those found by other authors who used colorimetric methods for that determination. Thus, Wegelius and von Knorring ${ }^{18}$, using Neuman and Logan's method ${ }^{12}$, found in the left ventricular myocardium of necropsy patients a mean hydroxyproline concentration of $3.98 \mu \mathrm{g} / \mathrm{mg}$ of dry tissue weight. Zwolinski et al ${ }^{19}$ used Stegemann and Stalder's method ${ }^{20}$ to

\begin{tabular}{|c|c|c|c|}
\hline $\begin{array}{l}\text { Table I-Comparison between th } \\
\text { formalin-fixed or nonfixed left v } \\
\text { and the percentage of fibrosis }\end{array}$ & $\begin{array}{l}\text { hydroxyprol } \\
\text { tricular myc } \\
\text { leasured by }\end{array}$ & $\begin{array}{l}\text { line (Hyp) conce } \\
\text { ocardium (LVM } \\
\text { a morphometri }\end{array}$ & $\begin{array}{l}\text { ntrations in } \\
\text { 1) specimens } \\
\text { ic method }\end{array}$ \\
\hline \multirow[b]{2}{*}{ Parameters } & \multicolumn{2}{|c|}{$\begin{array}{l}\text { Concentration of Hyp } \\
\text { ( } \mu \mathrm{g} / \mathrm{mg} \text { of dry weight) }\end{array}$} & \multirow{2}{*}{$\begin{array}{l}\text { Percentage } \\
\text { of } \\
\text { fibrosis }\end{array}$} \\
\hline & fixed LVM & nonfixed LVM & \\
\hline Median & 4.5 & 4.3 & 11.41 \\
\hline Minimum and maximum values & $1-11$ & $0.8-10.77$ & $4.73-36.73$ \\
\hline
\end{tabular}

determine the concentration of hydroxyproline in left ventricular myocardium samples of necropsy patients and found the value of $5.49 \mu \mathrm{g} / \mathrm{mg}$ of dry tissue weight. Hoyt et $\mathrm{al}^{21}$ used Woessner's method ${ }^{22}$ to quantify hydroxyproline in 2 normal and 8 moderately fibrosed human hearts, all of them previously fixed in $4 \%$ buffered formalin, and found mean concentrations of 5 and $38.4 \mu \mathrm{g} / \mathrm{mg}$ of dry weight, respectively. Correa de Araújo ${ }^{23}$, using Stegemann and Stalder's method ${ }^{20}$ modified by Medugorac ${ }^{17}$, found in the left ventricular myocardium of noncardiopathic necropsy patients a hydroxyproline concentration of $5.26 \mu \mathrm{g} / \mathrm{mg}$ of dry tissue weight; in patients with chronic Chagas heart disease, this concentration varied between 4.84 and $5.02 \mu \mathrm{g} / \mathrm{mg}$, and in patients with hypertensive heart disease, the concentration was $2.05 \mu \mathrm{g} / \mathrm{mg}$. Taking these cases into account, the mean hydroxyproline concentration was $4.02 \mu \mathrm{g} / \mathrm{mg}$ of dry tissue weight. Other authors ${ }^{24}$, who studied subendocardial biopsies of the left ventricular myocardium of noncardiopathic patients and of others with constrictive pericarditis, kept in liquid nitrogen, found mean hydroxyproline concentrations of 6.1 and $10.9 \mu \mathrm{g} / \mathrm{mg}$ of dry tissue weig-

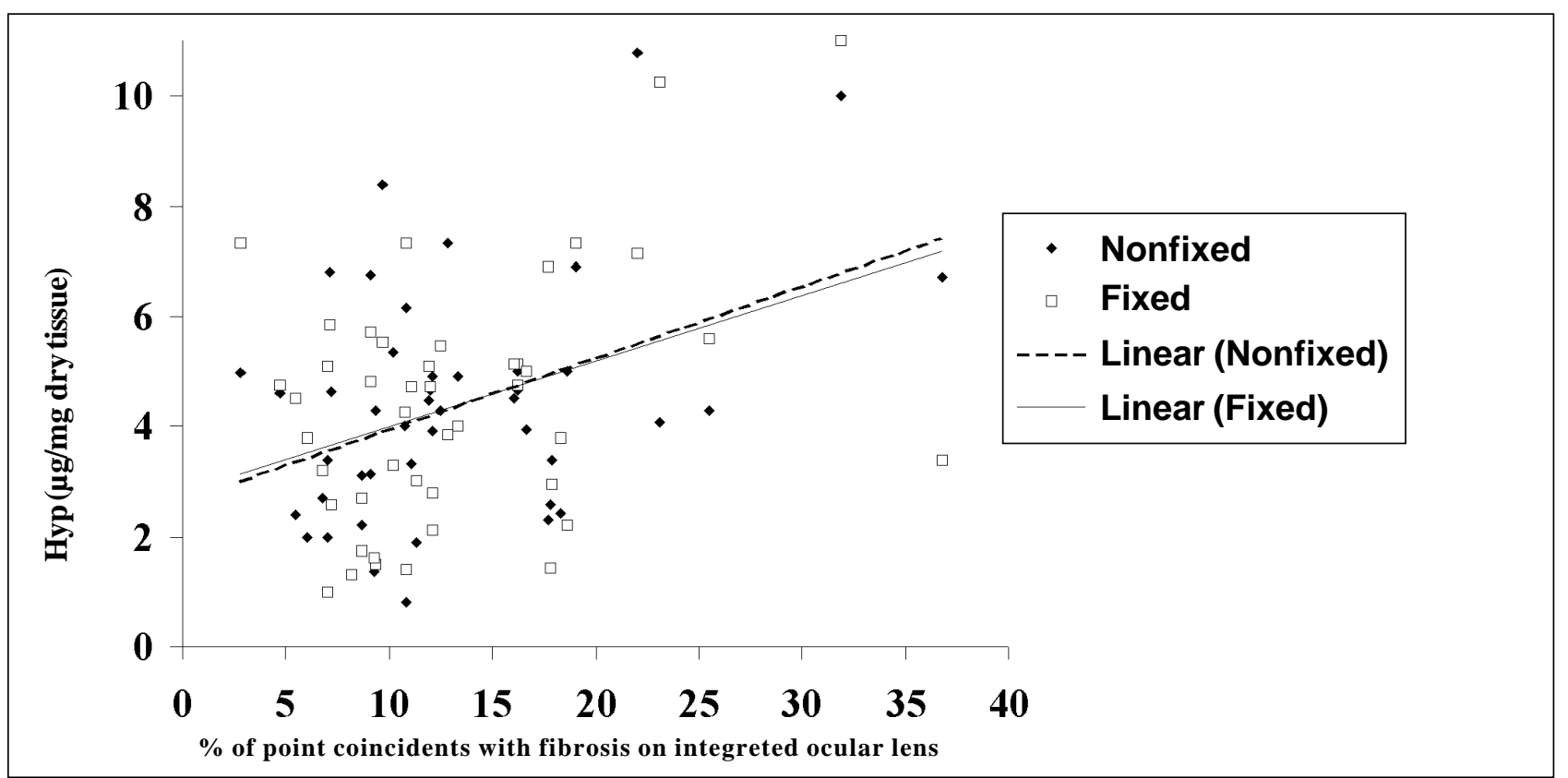

Fig. 1 - Correlation between the hydroxyproline (Hyp) dosage in 10\% formaldehyde-fixed and nonfixed left ventricular myocardium specimens and the percentage of dots of the integrating ocular lens that are coincident with fibrosis in the left ventricular myocardium of necropsy patients. 
ht, respectively. Other studies report values of hydroxyproline, collagen concentrations, or both, in the left ventricular myocardium, determined by photocolorimetric methods ${ }^{25-29}$. However, in these reports, the results were expressed in $\mu \mathrm{g}$ of hydroxyproline/mg of humid tissue weight, without mentioning the water content of the samples. The possibility of quantifying collagen from the dosage of Syria red and of picric acid, after a picrosirius staining ${ }^{30}$, has to be pointed out.

Although several reports exist in the literature on the quantification of collagen done by the concomitant utilization of the photocolorimetric and the morphometric methods ${ }^{21,23,29,31-35}$, in only 2 of these reports ${ }^{21,31}$ are the correlations between the methods described. Takahashi ${ }^{31}$ caused myocardial necrosis in rats by intraperitoneal injection of isoproterenol. The concentration of hydroxyproline in the myocardium was measured by the photocolorimetric method $^{36}$, and the percentage of fibrosis was determined with a device that allows projection of the sections on a screen with 300 dots. The correlation found was positive and statistically significant $(r=0.79 ; \mathrm{p}<0.05)$. However, the author did not mention which region was studied, nor whether the fragments were fixed or not. In another study ${ }^{21}$, formalin-fixed fragments of the free left ventricle wall were analyzed; the concentration of hydroxyproline was determined by a photocolorimetric method ${ }^{24}$, and the morphometry was performed by using a computer-assisted image analysis system. A positive and significant correlation ( $\mathrm{r}=0.98$; $\mathrm{p}<0.01$ ) was found. In a third study ${ }^{34}$, a comparison was made between the biochemical and the morphometric methods, and a positive and significant correlation was found $(r=0.89 ; p<0.05)$; however, the values of the hydroxyproline dosage are not expressed.

In this study, the correlations between the hydroxyproline concentrations in the left ventricular myocardium and the percentages of fibrosis were positive, and the values were lower than those found in the 2 previously mentioned studies ${ }^{21,31}$. However, the data obtained in the present investigation are not comparable to those presen- ted in those 2 studies, because one of them ${ }^{31}$ used test animals, fibrosis was pharmacologically induced, and the photocolorimetric method used for the determination of the hydroxyproline concentration was different from the one used in this study. In the other study ${ }^{21}$, the authors also used a biochemical and mainly a morphometric method different from those used in this investigation.

Another factor that may have contributed to the low correlation coefficients between the concentration of hydroxyproline and the percentage of fibrosis is the distribution of the connective neoformation observed in some cardiopathies found in the patients studied. Some samples were obtained from hearts with diseases in which fibrosis is distributed in a focal manner, as in the case of chronic Chagas cardiopathy ${ }^{37}$ and of ischemic cardiopathy ${ }^{32,33,38}$. Thus, it is possible that the fragments used in the determination of the hydroxyproline concentration, although adjacent to those used in the morphometric study, did not have precisely the same collagen content.

In conclusion, despite some small differences, a positive correlation existed between the intensity of fibrosis morphometrically quantified in histologic sections of the left ventricular myocardium and the biochemically determined concentration of hydroxyproline, particularly when this determination was made on nonfixed left ventricular myocardium specimens. Currently, the method considered the gold standard for collagen quantification in the myocardium is the biochemical method associated with the use of a computer-assisted image analysis system ${ }^{34}$. The present study proves that the biochemical methodology is adequate and that manual morphometry has limitations that can interfere with the statistical significance of correlations used to estimate the intensity of fibrosis in the human myocardium.

\section{Acknowledgments}

The financial support of "Fundação de Ensino e Pesquisa de Uberaba" (FUNEPU), of "Fundação de Amparo à Pesquisa do Estado de Minas Gerais" (FAPEMIG) and of "Conselho Nacional de Pesquisa" (CNPq) is acknowledged.

\section{References}

1. McClain PE. Characterization of cardiac muscle collagen. J Biol Chem 1974; 249: 2203-11.

2. Laurent GJ, Cockerill P, McAnuty RJ, Hastings IRB. A simplified method for quantification of the relative amounts of type I and type III collagen in small tissue samples. Anal Biochem 1981; 113: 301-12.

3. Junqueira LCU, Bignolas G, Brentani RR. Picrosirius staining plus polarization microscopy, a specific method for collagen detection in tissue sections. Histochem J 1979; 11: 447-55.

4. Pelouch V, Dixon IMC, Golfman L, Beamish RE, Dhalla NS. Role of extracellular matrix proteins in heart function. Mol Cell Biochem 1994; 129: 101-20.

5. Weber KT, Janicki JS, Pick R, et al. Collagen in the hypertrophied, pressure-overloaded myocardium. Circulation 1987; 75(suppl I): I-40-7.

6. Iimoto DS, Cowell JW, Harper E. Increase in cross-linking of type I and type III collagen associated with volume-overloaded hypertrophy. Circ Res 1988; 63: 399-408.
7. Weber KT, Pick R, Jalil JE, Janicki JS, Carroll EP. Patterns of myocardial fibrosis. J Mol Cell Cardiol 1989; 21(suppl V): 121-31.

8. Bashey RJ, Martínez-Hernandez A, Jimenez AS. Isolation, characterization, and localization of cardiac collagen type IV. Association with other extracellular matrix components. Circ Res 1992; 70: 1006-17.

9. Weber KT. Cardiac interstitium in health and disease: the fibrillar collagen network. J Am Coll Cardiol 1989; 13: 1637-52.

10. Murray D, Keeley FW. The extracellular matrix. In: Murray RK, GrannerDK, Mayes PA, Rodwell VW (eds.). Harper's Biochemistry, $25^{\text {th }}$ edition. Norwalk: Lange, 1966: 625-35.

11. Berg RA. Determination of 3- and 4-hydroxyproline. Methods Enzymol 1982; 82: 372-8.

12. Neuman RE, Logan MA. The determination of hydroxyproline. J Biol Chem 1950; 184: 299-306.

13. Medugorac I. Characterization of intramuscular collagen in the mammalian left ventricle. Basic Res Cardiol 1982; 77: 589-98. 
14. Medugorac I, Jacob R. Characterisation of the left ventricular collagen in the rat. Cardiovasc Res 1983; 17: 15-21.

15. Lowry OH, Gilligan DR, Katersky EM. The determination of collagen and elastin in tissues, with results obtained in various normal tissues from different species. J Biol Chem 1941; 139: 795-804.

16. Bergman I, Loxley R. Two improved and simplified methods for the spectrophotometric determination of hydroxyproline. Anal Chem 1963; 35: 1961-5.

17. Medugorac I. Myocardial collagen in different forms of heart hypertrophy in the rat. Res Exp Med (Berlin) 1980; 177: 201-11

18. Wegelius $\mathrm{O}$, von Knorring J. The hydroxyproline and hexosamine content in human myocardium at different ages. Acta Med Scand 1964; 175: 233-7.

19. Zwolinski RJ, Hamlin CR, Kohn RR. Age-related alterations in human heart collagen. Proc Soc Exp Biol Med 1976; 152: 362-3.

20. Stegemann H, Stalder K. Determination of hydroxyproline. Clin Chim Acta 1967; 18: 267-73

21. Hoyt RH, Ericksen E, Collins SM, Skorton DJ. Computer-assisted quantitation of myocardial fibrosis in histologic sections. Arch Pathol Lab Med 1984; 108: 280-3.

22. Woessner JF. The determination of hydroxyproline in tissue and protein samples containing small proportions of this imino acid. Arch Biochem 1961; 93: 440-7.

23. Correa de Araújo R. Estudo bioquímico do miocárdio humano normal e patológico, com especial ênfase à cardiopatia chagásica crônica. Tese de Mestrado, Universidade de São Paulo. Ribeirão Preto, 1985.

24. Chello M, Mastroroberto P, Romano R, Perticone F, Marchese AR. Collagen network remodelling and left ventricular function in constrictive pericarditis. Heart 1996; 75: 184-9.

25. Oken DE, Boucek RJ. Quantitation of collagen in human myocardium. Circ Res 1957; V: 357-61.

26. Leclercq JF, Swynghedauw B. Myofibrillar ATPase, DNA and hydroxyproline content of human hypertrophied heart. Eur J Clin Invest 1976; 6: 27-33.

27. Mukherjee D, Sen S. Alteration of collagen phenotypes in ischemic cardiomyopathy. J Clin Invest 1991; 89: 1141-6.
28. Marijianowski MMH, Teeling P, Mann J, Becker AE. Dilated myocardiopathy is associated with an increase in the type I/type III collagen ratio: a quantitative assessment. J Am Coll Cardiol 1995; 25: 1263-72.

29. Adler C-P, Neuburger M, Herget GW, Mühlbach D. Regeneration processes in human myocardium after acute ischaemia - quantitative determination of DNA cell number and collagen content. Virchows Arch 1997; 430: 149-53.

30. Lopez-De Leon A, Rojkind M. A simple micromethod for collagen and total protein determination in formalin-fixed paraffin-embedded sections. J Histochem Cytochem 1985; 33: 737-43.

31. Takahashi S. A study on myocardial fibrosis in myocardial infarction and in idiopathic cardiomyopathy: a measurement of hydroxyproline level in plasma and in myocardium. Jpn Circ J 1979; 43: 913-21.

32. Eghbali M,Eghbali M, Robinson TF, Seifter S, Blumenfeld OO. Collagen accumulation in heart ventricles as a function of growth and aging. Cardiovasc Res 1989; 23: 703-29.

33. Factor SM, Butany J, Sole MJ, Wigle D, Williams WC, Rojkind M. Pathologic fibrosis and matrix connective tissue in the subaortic myocardium of patients with hypertrophic cardiomyopathy. J Am Coll Cardiol 1991; 17: 1343-51.

34. Kitamura M, Shimizu M, Kita Y, et al. Quantitative evaluation of the rate of myocardial interstitial fibrosis using a personal computer. Jpn Circ J 1997, 61: 781-6.

35. Laguens RP, Castagnino HE, Jorg ME, Hamamura S. Reduced injury and scar in acute myocardial infarctions treated with human growth hormone. Jpn Heart J 1998; 39: 809-17.

36. Prockop DJ, Udenfriend S. A specific method for the analysis of hydroxyproline in tissues and urine. Anal Biochem 1960; 1: 228-39.

37. Raso P, Toppa NH. Tipos de colágeno nas áreas de fibrose da cardiopatia chagásica crônica com lesão vorticilar esquerda e insuficiência cardíaca. Rev Soc Bras Med Trop 1983; 16: 184-8.

38. Bishop JE, Greenbaum R, Gibson DG, Yacoub M, Laurent GJ. Enhanced deposition of predominantly type I collagen in myocardial disease. J Mol Cell Cardio 1990; 22: 1157-65. 